\title{
Impact of Diversity Management on Employees' Engagement: The Role of Organizational Trust and Job Insecurity
}

\author{
Ayman Alshaabani * (i), Khadija Aya Hamza (i) and Ildikó Rudnák (i) \\ Institute of Agricultural and Food Economics, Hungarian University of Agriculture and Life Sciences, \\ 2100 Gödöllo, Hungary; khadija.hamza@yahoo.fr (K.A.H.); Rudnak.Ildiko@uni-mate.hu (I.R.) \\ * Correspondence: a.shaabany@gmail.com; Tel.: +36-70-613-0097
}

check for updates

Citation: Alshaabani, A.; Hamza, K.A.; Rudnák, I. Impact of Diversity Management on Employees'

Engagement: The Role of

Organizational Trust and Job

Insecurity. Sustainability 2022, 14, 420 https://doi.org/10.3390/su14010420

Academic Editor: Hyo Sun Jung

Received: 12 December 2021

Accepted: 28 December 2021

Published: 31 December 2021

Publisher's Note: MDPI stays neutral with regard to jurisdictional claims in published maps and institutional affiliations.

Copyright: () 2021 by the authors. Licensee MDPI, Basel, Switzerland. This article is an open access article distributed under the terms and conditions of the Creative Commons Attribution (CC BY) license (https:// creativecommons.org/licenses/by/ $4.0 /)$.

\begin{abstract}
The frequent world changes raised by globalization, new technology development, and the increase in migration movements have generated an immensely diversified workforce. To face these challenges, managers started to seek the best strategies to effectively run this mixed environment and implement the leading diversity management policies for human resource management sustainability, which is also considered as very constructive in boosting employees' performance, motivation, satisfaction, as well as their work engagement. Consistently, this paper examines the impact of service companies' diversity management systems on employees' engagement and the moderating role of organizational trust and job insecurity in that relationship. As we opted for a quantitative study, we managed a survey based on a questionnaire dedicated to 580 employees working in Hungarian companies, specializing in Marketing, Management consulting, IT, and logistics services, to effectively assess the hypothesis concluded from the literature review. With the use of structural equation modeling (SEM) as a data analysis tool, our findings reveal that diversity management has a positive significant effect on Employees' engagement and that organizational trust and job insecurity truly and significantly mediate that association. Along with social exchange theory, our research contributes to affirming that by implementing proper diversity management practices and by ensuring a trustworthy environment and outstanding work conditions, managers are constructively able to assist their employees, raise their involvement, and minimize the level of job insecurities.
\end{abstract}

Keywords: diversity management; employees' engagement; organizational trust; job insecurity

\section{Introduction}

Presently, with the world change, the rise of globalization, technology development, and migration movements, the work environment has become progressively diversified and mixed [1]. These facts were the main reasons for many changes within the business sector where women, disabled people, and individuals who have different demographic and socio-cultural characteristics were mostly affected [2]. At the beginning of the 1990s, several managers started to encounter the new tendency of diversity at the workplace, which was raised by the implementation of liberalization, privatization, and globalization policies [3]. At that time, the topic started to have a huge consideration from researchers perspective, where some scholars have mentioned that sooner or later companies' structures might reach $90 \%$ of women and many of them would be migrants. Without forgetting the racial groups that will present the largest part of the companies' businesses [4,5]. According to them, the organizations that will appreciate these changes will be more competitive in the markets and will respond to a vast variety of approaches to managing their diversified workforce [3].

It was also highly mentioned that diversity management is increasingly important in ensuring the human resource management sustainability, where [6] confirmed that organizations who guard their diversified workforce by planning a long term diversity management strategies and include them in the companies' human resource management 
activities such as recruitment, payroll, mobility, promotion etc., who ensure structured employees' evaluations and who have the right managers with international and multicultural experiences, flexible and global mindsets, and strong diversified technical and strategical skills are those who succeed in introducing supportive programs for sustainability and a skilled, powerful, and solid work environment. In addition, they reported that diversity implementation with its full requirements incarnated into the firms' everyday life can ensure the companies' sustainable prosperity in a very globalized world.

From the Hungarian outlook, researchers pointed out that some of the Hungarian employers started to deliver greater importance to promote diversity in the workplace, by considering the diversity management not only from recruiting diversified employees' but also from ensuring them the feeling of organizational involvement and equity in the management policies [7], other Hungarian employers still refuse to address this issue because of the lack of trust [8]. To conclude, one of the best ways to keep the highest competitiveness is then to admit that today's liveware is progressively mixed and diverse. That is why huge efforts in promoting policies and practices are needed to ensure individuals' inclusion from all backgrounds and push them to reach some positive outcomes such as profitability, creativity, flexibility, organizational growth, organizational trust, and employee engagement [9]. These positive outcomes also need some other fundamental measures and changes in the organizational structure such as human resource policies, operational procedures, style of leadership, and well-structured organizational culture [3].

Earlier, from a theoretical stance, the institutional theory was basically used to state that diversity management is about the rules and norms settled by the company to influence the employees' behaviors [10]. In the same line, some other studies have mentioned that corporate ethics enhancing peoples' sense of respect towards each other ensures organizational commitment [11,12]. In addition, social exchange theory shaped that exchange is the best way to show appropriate behaviors valuable to their organization [13]. Hence, our study will focus on exploring this effect in the Hungarian context, as in some of the local companies the concept of diversity acceptance is still frozen out. We would like to see how the actual changes (migrants' movement, technology development, openness) impacted the diversified Hungarian work environment and how Hungarian managers in service companies started to deal with this issue to ensure their employees' engagement. According to Guadagno [14], the foreigner employees' segment was the most vulnerable and intensely affected during crisis time (COVID-19 pandemic for instance) due to different reasons, such as the difficult living circumstances, different working conditions, inadequate health services, limited local knowledge, and shortage of government foreigners' support, etc. These facts have pushed us to focus on this type of employees, in order to understand the effectiveness of diversity management policies implementation in boosting their engagement at work.

Correspondingly, Karatepe has mentioned in his study, that employees retain a lower work engagement, in an environment full of job loss fear and lack of great management. Contrarily, employees who are full of energetic and enthusiastic feelings towards their job are usually up to show greater attitudinal and behavioral outcomes [15]. Consequently, these studies have reported that job insecurity, which is considered as a sensation felt by employees when there is a risk of job loss [16], is the reason for lack of engagement and engenders detrimental outcomes such as nonattendance behaviors and counterproductive work behaviors [17]. Because of the lack of studies dealing with this issue, our study will try to investigate on reporting the mediation effect of job insecurity in the relationship between diversity management and employee engagement.

Even though employee engagement was linked to many job outcomes as we mentioned before, there are few studies that point to the antecedents of engagement such as leadership and trust [18]. That is why understanding the role of trust is a key point to generate positive job attitudes. From this standpoint, Ugwu et al. [18] confirmed that trust is a key factor for any organization to ensure their employees' wellbeing because trust maintains social exchange and ensures positive job attitudes such as being more engaged at work. 
Hence, the current study will try to explore the mediation role of organizational trust in the relationship between diversity management and employees' engagement. In addition, the researchers truly consider the current study as an important contribution, bringing an additional value to the literature, as no earlier studies were conducted in Hungary linking diversity management, organizational trust, job insecurity, and employee engagement variables all together.

For the results' examination, the researchers opted for a quantitative study using a questionnaire as a data collection tool sent to 580 respondents from Marketing, Management consulting, IT, and logistics at local Hungarian service companies. The findings show how important it is for Hungarian managers to ensure a well-structured diversity management strategy in promoting their employees' work engagement and avoiding sensations of job insecurity. It also shows how trust in the organization could be a significant factor to boost that engagement.

This paper is then structured as follows, it firstly starts with a literature review containing all concepts, definitions, and links between the model variables from which the researchers concluded our hypothesis. Then, the methodology part took place followed by the results, discussion of the data analysis, and as a conclusion, the researchers have tried to summarize all the theoretical and practical contributions and, finally, state the limitations and suggestions for future research.

\section{Literature Review}

\subsection{Diversity Management and Employee's Engagement}

Diversity management was largely considered as a general concept, originally taken as a replacement for and reframing of the earlier affirmative action programs and the equal employment opportunities act in the United States [19]. Many authors introduced this concept to help in promoting employment and career development and combating racial and gender discrimination [20].

Previously, the diversity issue was thoroughly ignored in organizations. However, with the world changes due to globalization, diversity management started to gain a lot of consideration, and many authors started to examine it from different angles and different viewpoints [21]. Regarding its definition, investigators have mentioned that the concept is seen as a general and vast notion, hard to be defined in a single and concrete conceptualization [21]. In compliance with this fact, Jackson et al. [22] have mentioned that diversity is the existing dissimilarities in personal attributes between people who are working in the same groups, and these attributes usually include (age, gender, race, etc.). In addition, Yadav and Lenka [21] (p. 1), added that diversity management is a perspective to "enhance the performance of a heterogeneous workforce and inclusive development of people with differences in gender, ethnicity, nationality, cultural and educational backgrounds". Furthermore, Thomas [23] defined the concept as a practice that consists of implementing diversity through effective change within the organization, which has a positive effect on promoting the achievement of the planned objectives. This variation in the definitions gives an idea about the complexity of the diversity concept.

In this line, many theories were related to diversity management in order to explain its importance and necessity within organizations, such as, for example, the social identity theory [24], explaining that individuals usually classify their perceptions according to the social groups and based on some common attributes; similarity-attraction theory [25], highlighting that individuals are willing to be closer to those who share similar attributes and attitudes and put themselves in challenging situations with those who dispose different attitudes, values, and experiences; and finally, the social exchange theory [26], reporting the importance of the mutual exchange that grants social stability. Therefore, a safe environment could be created when effective diversity management is implemented within the organizations where people are willing to engage and commit.

Literature on engagement states that employee engagement is considered as a very recent topic, where authors started to take it into consideration and talk about it widely in 
2000 [27]. Several definitions were dedicated to conceptualizing the notion. Accordingly, Ref. [28] have mentioned that employee engagement is the degree of his/her attachment to the organization and how they identify themselves towards it. It has also been reported that employee engagement can occur when people are engaged in their work, and they are concerned and enthusiastic about their job and position and willing to put a lot of effort into it [27]. Furthermore, Kahn [29] (p. 694) who was the first one who introduced the concept, added that employee engagement can occur when "people employ and express themselves physically, cognitively, and emotionally during role performances".

In this line, we can say that employee engagement aims to enhance the performance, autonomy, diversity respect, integrity, and personal development [27]. In their study, Schaufeli et al. [30] have mentioned that there are three factors of employee engagement, which are vigor, dedication, and absorption, where "Vigor is characterized by high levels of energy and mental resilience while working, the willingness to invest effort in one's work, and persistence even in the face of difficulties and where dedication refers to being strongly involved in one's work and experiencing a sense of significance, enthusiasm, inspiration, pride, and challenge and finally, absorption which is characterized by being fully concentrated and happily engrossed in one's work, whereby time passes quickly, and one has difficulties with detaching oneself from work." [31] (p. 702).

Previous studies, widely focused on the press, on social exchange theory to explain that higher employee engagement can be reached through providing the right resources and the right support by the organizations [32]. From this standpoint, many authors tried to indicate that diversity practices are the way to show the employees how the organization cares about their differences and try always to keep in mind that reaching their happiness is the most important objective [33]. In this line, anterior research confirmed this relationship by mostly focusing on the effect of fairness, development provision, and ethical climate presence on employee satisfaction and engagement [34,35]. In addition, Hapsari et al. [36] reported that employee engagement is highly linked to job satisfaction, organizational commitment, job involvement, and feelings of empowerment, highlighting that thanks to those feelings, employees are willing to work harder and adapt themselves to the company's values and goals. Furthermore, in a recent study, Alshaabani et al. [37] found that perceived organizational support positively impacts the employees' engagement. These results, which was in line with SET, indicated that during the COVID-19 pandemic, the role of management in providing support to the employees is significant for enhancing their engagement at work which in turn was positively affecting their organizational citizenship behaviors.

Thus, managers must take into consideration all these features and keep in mind that diversity plays extraordinary importance in business because it offers big benefits to both the employer and the employees, who will be satisfied and engage in their jobs [36]. Very few studies have linked diversity management to employee engagement such as Downey et al. [9], who, by adopting a survey dedicated to 4597 health sector employees, confirmed that having clear diversity management practices and policies plays a significant role in boosting employees' engagement. Similarly, Alshaabani and Benedek [38], with sending an online questionnaire to 202 employees with Middle Eastern nationalities and working in Western countries, reported that some diversity management practices, such as training, performance appraisal, and recruitment, play an important role in increasing Egyptian workers' engagement levels. In addition, Skalsky and McCarthy [39] have also mentioned in their research, that diversity training was the most effective practice in enhancing employee engagement levels among Australian employees. From this perspective, we can conclude our first hypothesis:

Hypothesis 1 (H1). "Diversity management has a significant positive effect on employees' engagement." 


\subsection{Mediation Role of Organizational Trust}

According to the literature, we were able to notice that researchers mostly focused on either interpersonal trust or organizational trust [40]. In the current research, the focus will mainly be on organization trust, which was defined by Hon and Grunig [41] (p. 3) as "one party's level of confidence in and willingness to open oneself to the other party," and by Nyhan and Marlowe [42] as a global assessment of an organization's trustworthiness. Berraies et al. [40] have mentioned that organizational trust can be seen through employees' reliance and through how the organization will treat them fairly and will respect their different interests with different practices.

The literature review on organizational trust presented three dimensions defining the concept which are as follows: integrity, which consists of believing that the organization will perform justly and consider everyone's expectations; then dependability, highlighting that the organization should keep its promises to increase the level of trust within employees; and finally, competence, stating that the organization can fulfill its promises [43]. In addition to this, many researchers have recognized that there are many factors that can be put up to build and boost organizational trust within companies such as employee empowerment, cultural norms, organizational structure, organizational justice, and distributed leadership $[40,44]$. In that context, we will try to explore a non-documented area, which is how diversity management can promote organizational trust.

It is obvious to see that diversity management and trust in organizations can be highly connected, and this could be explained by the fact that diversity management consists of not only employing different people but also ensuring their inclusion within the organization $[7,45]$. It is very important that employees feel they are needed for the company's decision-making process so that they will automatically show positive attitudes and be more engaged; even so, this kind of environment cannot be settled without the concept of trust.

In this line, it has been widely mentioned that diversity management is the best practice to ensure fairness, respect, appreciation, and engagement, which can also contribute to increasing the level of organizational trust [10,12,46]. Alas and Mousa [47] reported that if the organization accepts people as they are with respect to fair treatment, positive consequences may occur leading to an increase in employee motivation and other positive outcomes such as job satisfaction, organizational citizenship behavior, loyalty, performance, and trust. From this perspective, we can suggest our second hypothesis:

\section{Hypothesis 2 (H2). "Diversity management has a significant positive effect on organizational trust."}

In their study, Ugwu et al. [18] explained that engagement was related to several variables at the organizational level such as leadership [48], need for achievement [49], organizational justice [44,50], and organizational tenure [51]. In addition to these variables, in some other studies, researchers stated the importance of organizational trust in increasing employee engagement. Thus, organizational trust is seen as a vital factor promoting employee performance, organizational commitment, and work engagement [52].

Accordingly, Wong et al. [53] have found that thanks to the organizational trust that helps in increasing knowledge exchange, employee engagement can be boosted thereafter. Thus, a direct positive effect was proven between organizational trust and employee engagement. In the same line, it turned out that trust helps employees in completing their jobs and respects their duty towards the company that they are working for [18]. From this point, most of the researchers explained this relationship by the social exchange theory, which states that if the employees trust that the organization treats them fairly, they tend to reciprocate the treatment. As conclusion then, trust is a necessary factor to make the employees concentrate on their work, feel concerned about the whole companies' issues, and feel motivated to be more engaged [18]. From this perspective, we can suggest our third hypothesis: 
Hypothesis 3 (H3). "Organizational trust has a significant positive effect on employee engagement."

In recent studies, many researchers tried to investigate the mediating role of organizational trust between many variables such as between corporate social responsibility and employee engagement [54], confirmed by a survey made for 485 employees working in the Indian banking sector. In addition, organizational trust was studied as a mediator between corporate social responsibility and organizational commitment [55], based on a survey made through 289 Vietnamese pharmaceutical enterprises. Moreover, other studies studied organizational trust as a mediator between diversity management and other variables such as knowledge sharing [56], turnover intentions [57], and counterproductive behaviors [38]. However, the current study will investigate confirming the mediation role of organizational trust between diversity management and employee engagement. Therefore, as conclusion from Hypothesis 2 and Hypothesis 3. we can suggest our Hypothesis 4 stating that:

Hypothesis 4 (H4). "Organizational trust mediates the relationship between diversity management and employee engagement."

\subsection{Mediation Role of Job Insecurity}

Discussions around job insecurity commence having huge importance starting from the 1980s, when researchers argued that the concept is highly related to motivation theory [58]. To define the notion, Jung et al. [59] explained that job insecurity occurs when workers feel worried about losing their job and being obliged to face unemployment. In another word, job insecurity is when employees are threatened to lose their job features because of economic forces (recession, industry downturn) organizational restructuring, and interpersonal factors [60]. Many scholars insisted on the fact that job insecurity is considered a psychological factor affecting employees' physical and mental health [61] and is able to reduce workers' motivation and engagement [58]. Furthermore, previous studies have tried to probe more into the concept, such as Hellgren et al. [62], who have proposed qualitative and quantitative perspectives of job insecurity. They have mentioned that the qualitative perspective is about employees' concern towards their future job conditions and situation and that the quantitative perspective is about the sequels resulting from losing their job [63]. Additionally, Sverke and Hellgren [64] took different angles for job insecurity and stated the cognitive and affective aspects. They reported that cognitive insecurity is about employees' interpretation of the organization and effective insecurity is about their evaluation of the situation.

In fact, many studies have investigated several predictors and moderators of job insecurity, as well as the factors that are able of weakening that variable some of the predictors of job insecurity can contain labor market characteristics, organizational change, organizational communication, employment contract, uncertainty in the future of the company, perceived control and employability, role conflict and ambiguity, family control, and the need for security $[64,65]$. On the other hand, other researchers indicated the role of human resources management in reducing or preventing job insecurity and in building trust between the employees and the management $[66,67]$. Since diversity management has a set of practices of human resources management, therefore, our study will make a better understanding of diversity management's impact on job insecurity. Along with this idea, Lavaysse et al. [68] suggested, according to collected data from 449 employed individuals within the United States, that diversity management can be an effective method for reducing job insecurity, especially among minorities. In the same line, Shen et al. [69], with collected data from 530 Chinese employees working in different fields and industries, noted that the absence of diversity management could lead to higher levels of job insecurity, job injustice, and less fair payment, which in turn could negatively affect the employees OCB. Hence, the following hypothesis can be suggested:

Hypothesis 5 (H5). "Diversity management has a significant negative effect on Job insecurity." 
In addition to the predictors and moderators of job insecurity, the concept itself can have a negative impact on employees' performance, motivation, satisfaction, as well as engagement. Sharing these thoughts, Greenhalgh and Rosenblatt [70] have mentioned that if employees are facing a high level of job insecurity, they are more likely to feel less engaged toward their work and make little effort to follow and reach the organization's goals and objectives. In the same line, Presti and Nonnis [71] confirmed that employee's emotional commitment is hugely and negatively affected by job insecurity, which can also make their happiness and wellbeing inconsistent [72]. Likewise, Wang et al. [73] stated that employees' job performance can be declined and decreased due to job insecurity impact, and that is why workers may feel less engaged in their work. This idea was also shared by Getahun and Chang [74]. The negative effect of job insecurity does not directly prevail only on the attitudes or behaviors of the employees, but it can be reflected negatively on the employees' physical, psychological, and mental energy, which can decrease their engagement consequently [17]. We can, then, suggest our Hypothesis 6:

Hypothesis 6 (H6). "Job insecurity has a significant negative on employee engagement."

Many studies have looked over the mediating role of job insecurity between many variables, such as the study of Park and Ono [75], who explained how job insecurity could be a mediator between workplace bullying and work engagement with confirmed data from employees in Korea using the latent factor approach, as well as the study of Hsieh and Huang [76], who also studied the mediating role of job insecurity in peoples' core self-evaluation and their job satisfaction, based on a survey made through 346 full-time employees in Taiwan. Furthermore, De Beer et al. [77] indicated that HR practices that aim to eliminate discrimination at the workplace and manage diversity can decrease the job insecurity between the black employees which, in turn, affects their job turnover, whereas it does not have any effects on their white fellows. From this perspective, we are interested in seeing the importance of diversity management in employees' engagement toward their jobs to make more effort and have more energy and motivation to follow their companies' goals and objectives. As a conclusion from the Hypothesis 5 and Hypothesis 6, we can suggest our Hypothesis 7 as follows:

Hypothesis 7 (H7). "Job insecurity mediates the relationship between diversity management and employee engagement."

Based on what was mentioned above, the proposed study's model is presented in Figure 1.

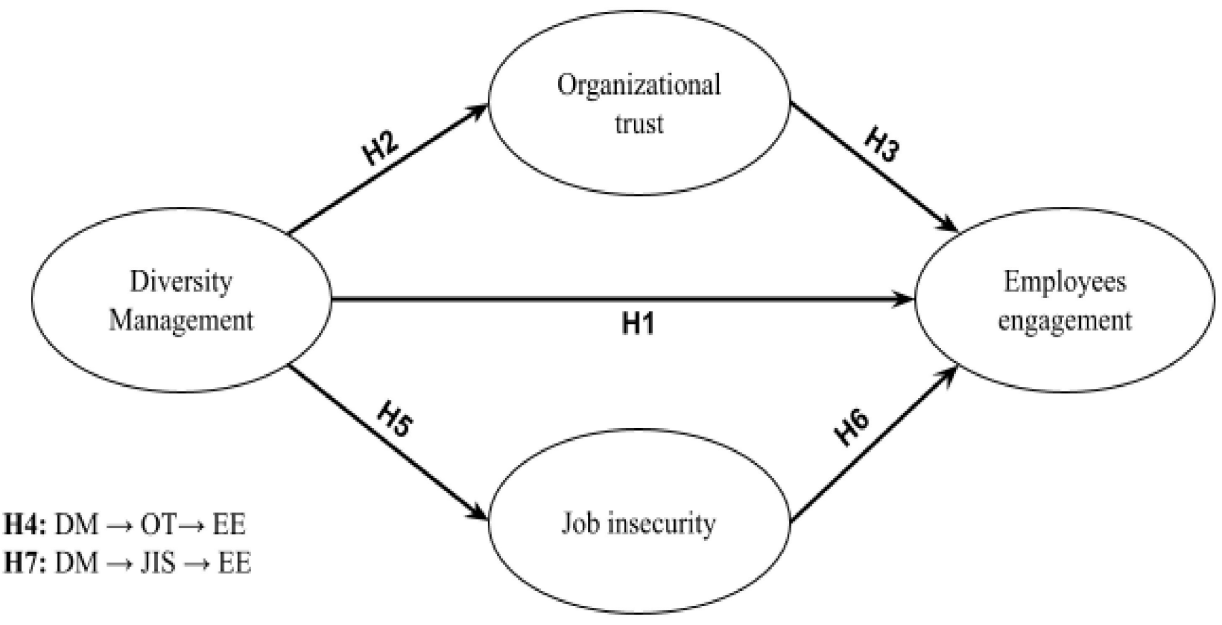

Figure 1. The study model. 


\section{Materials and Methods}

\subsection{Sample and Procedures}

The targeted population of this study was the employees of different private companies in the Hungarian service sector. A self-administrated questionnaire was prepared in an online form and sent by online platforms (Facebook, LinkedIn, and e-mails). Snowball sampling method was used in collecting responses. First, the researchers sent the questionnaire to their friends who work for private service companies in the following fields (marketing services, consulting management services, IT services, and logistics services), and then these employees forwarded the questionnaire to their colleagues and friends, who later shared it with their friends. The total number of questionnaires that were sent to possible participants was 580 requests. The number of received responses was 378 with a rate of $65 \%$, which is an accepted response percentage [78]. Table 1 presents the personal characteristics of the sample.

Table 1. The personal characteristics.

\begin{tabular}{cccc}
\hline Variable & Item & Count & \% \\
\hline \multirow{2}{*}{ Gender } & "Female" & 58.6 & 41.4 \\
& "Male" & 214 & 61.1 \\
Age & "18-24 years" & 151 & 15.3 \\
& "25-34 years" & 77 & 2.5 \\
& "35-44 years old" & 223 & 32.9 \\
Job Tenure & "45-54 years old" & 56.6 \\
& "Less than a year" & 11.5 \\
"Between 1 and 5 years" & 120 & 3 \\
Education & "Between 4 and 10 years" & 192 & 10.7 \\
background & "Above 10 years" & 42 & 36.4 \\
& "High school" & 11 & 39.1 \\
& "Bachelor's degree" & 133 & 2.5 \\
& "Master's degree" & 139 & 12.3
\end{tabular}

Table 1 shows that most of the employees were males (58.6\%) belonging to the " 25 to 34 years old" age range $(62.7 \%)$. Furthermore, most of the respondents were having "between 1 and 5 years" job experience within the current working company (52.6\%). The educational background of the questioned people was mainly around bachelor's degree and master's degree. These percentages were not surprising for us, since they were very close to the personal characteristics of the employees of the service sector's organizations in Hungary as was mentioned in the report of [79]. According to Baksa et al. [79], females represent $59 \%$ of the employees in this sector, the average age of the employees is 33 years old, $78 \%$ of the employees hold university degrees, and the foreign employees present $14 \%$ of the total employment in that sector.

\subsection{Measures}

All constructs of this study were structured in a questionnaire comprising five sections built based on adapting previously validated scales from the literature; the respondents reported their levels of diversity management, job insecurity, organizational trust, and employee work engagement; and finally, respondent's general information was also added. The measures that were used in this study, the number of items, the source of each construct measurement, and a sample item are shown in Table 2. 
Table 2. The study's measures.

\begin{tabular}{|c|c|c|c|c|}
\hline Construct & Author(s) & Items No. & Example Item & Scale \\
\hline $\begin{array}{c}\text { Diversity } \\
\text { management }\end{array}$ & Bizri [10] & 6 & $\begin{array}{l}\text { "Employees' performance is evaluated objectively } \\
\text { regardless of religion, sect, or ethnicity." }\end{array}$ & \multirow{3}{*}{$\begin{array}{l}\text { "5-point scale ranging } \\
\text { from 1: strongly disagree } \\
\text { to 5: strongly agree" }\end{array}$} \\
\hline Job insecurity & $\begin{array}{l}\text { Chen and } \\
\text { Eyoun [80] }\end{array}$ & 4 & "I am afraid that I may not be able to keep my job." & \\
\hline $\begin{array}{c}\text { Trust in } \\
\text { organization }\end{array}$ & $\begin{array}{c}\text { Gabarro and } \\
\text { Athos [81] }\end{array}$ & 7 & $\begin{array}{l}\text { The scale was modified slightly from My employer } \\
\text { to my organization to fit the purpose of the study: } \\
\text { "My organization's management is open and } \\
\text { upfront with me" }\end{array}$ & \\
\hline $\begin{array}{c}\text { Employee } \\
\text { engagement }\end{array}$ & $\begin{array}{l}\text { Schaufeli } \\
\text { et al. [31] }\end{array}$ & 9 & "Time flies when I am working" & $\begin{array}{l}\text { "7-point scale ranging } \\
\text { from 1: Never disagree to } \\
\text { 7: Always/everyday" }\end{array}$ \\
\hline
\end{tabular}

In addition, the following controlling variables were included, in line with prior research: (i) gender ( $1=$ female, $2=$ male); (ii) age (" $1=$ from 18 to 24 " to " $5=$ older than 55 years old"); (iii) the job tenure (" $1=$ less than a year" to " $4=$ more than 10 years"); (iv) educational background (" $1=$ high school" to " $\left.6=\mathrm{PhD}^{\prime}\right)$; $(\mathrm{v})$ nationality $(1=$ Hungarian, $\mathrm{T})$.

Table 3 shows the descriptive analysis of the variables of the current study and their intercorrelations.

Table 3. Correlations and descriptive analysis $(\mathrm{N}=365)$.

\begin{tabular}{|c|c|c|c|c|c|c|c|c|c|c|}
\hline Variables & Mean & SD & 1 & 2 & 3 & 4 & 5 & 6 & 7 & 8 \\
\hline 1-Gender & 1.59 & 0.49 & - & & & & & & & \\
\hline 2-Age & 1.96 & 0.63 & 0.026 & - & & & & & & \\
\hline 3-Job tenure & 1.85 & 0.736 & -0.100 & $0.475 * *$ & - & & & & & \\
\hline 4-Education & 3.69 & 1.104 & 0.050 & $0.258 * *$ & -0.060 & - & & & & \\
\hline 5-Nationality & 1.29 & 0.456 & -0.070 & $0.195 * *$ & $0.208^{* *}$ & $-0.154^{* *}$ & - & & & \\
\hline 6-Diversity management & 3.66 & 0.611 & -0.035 & 0.075 & 0.071 & 0.030 & $0.186^{* *}$ & - & & \\
\hline 7-Job insecurity & 2.53 & 0.88 & -0.0115 * & 0.036 & -0.100 & 0.025 & $-0.240^{* *}$ & $-0.295 * *$ & - & \\
\hline 8-Trust in organization & 3.43 & 0.623 & -0.094 & 0.100 & 0.018 & $0.125^{*}$ & $0.260 * *$ & $0.507 * *$ & $-0.241^{* *}$ & - \\
\hline 9-Work engagement & 4.60 & 0.870 & 0.005 & -0.031 & -0.036 & $0.203^{* *}$ & 0.089 & $0.300 * *$ & $-0.295^{* *}$ & $0.400 * *$ \\
\hline
\end{tabular}

\subsection{Measurement Model}

To test the model fit, we used the recommendations of Schumacker and Lomax [82]. These recommendations suggest that before reaching conclusions about the study's model, diagnoses of the goodness fit of the study's model should be assessed. By using CFA, the researchers investigated the indices of the goodness fit of the study's model. While investigating the proposed framework, authors focused on convergence and discriminant reliability. The main indices to be reported according to $[82,83]$ include the "model's chisquare" $\left(\chi^{2}\right)$, "degree of freedom of the model" $(\mathrm{df})$, , the ratio of the chi-square statistic to the respective degrees of freedom $\left(\chi^{2} / \mathrm{df}\right)$ ", "comparative fit index" (CFI), the root mean square error of approximation (RMSEA), "the Tucker-Lewis index" (TLI), and "the standardized root mean residual" (SRMR). According to Awang [84], there are thresholds values of these indices that should be met to consider the model as a good fit, these recommended cutoffs values are $\chi^{2} / \mathrm{df}<5$, RMSEA $\leq 0.08$, CFI $>0.9$, TLI $>0.9$, and SRMR $<0.05$. Therefore, assessing the model fit prior to performing the final analysis is necessary. The key indices are presented in Table 4, indicating the goodness of the study' model fit.

Table 4. The goodness fit of the study's model.

\begin{tabular}{cccccccc}
\hline Fit Index & $\chi^{2}$ & df & $\chi^{2} / \mathbf{d f}$ & TLI & CFI & RMSEA & SRMR \\
\hline Total model & 72.239 & 17 & 4.249 & 0.91 & 0.92 & 0.076 & 0.05 \\
\hline
\end{tabular}




\subsection{Common Method Bias}

Since our data were obtained based on self-reporting of the respondents, this can raise concerns about potential common method bias-variance [85]. The variance is "attributable to the method of measurement instead of the measures that represent the constructs" [85] (p. 879). This bias can threaten the validity of the results of the current study [86]. For this purpose, "Harman's single-factor test" was used. In Harman's test, all the studied variables were loaded into one factor in an "explanatory factor analysis" (EFA) without rotation solutions of the factors. The results showed that the one-factor solution explained only $29.01 \%$ of explained variance. Favero and Bullock [87] suggested obtaining the data of dependent and independent variables from different resources as a way to remedy common method bias, which this study has applied to achieve the goal of avoiding common method bias.

\subsection{Reliability and Validity Tests}

To test the reliability of the constructs, the internal consistency of the study's constructs was examined using Cronbach's alpha. As was recommended by Sekaran and Bougie [88], the value of Cronbach's alpha of each construct should exceed the threshold of 0.60. In our case for all constructs, the values were exceeding 0.75 , indicating very good reliability of the data. Table 3 presents the values of Cronbach's alpha of each construct. Afterward, performing reliability and validity tests are necessary to assess the validity of the data.

To evaluate the variables' validity, two validity tests were used: "convergent validity $(\mathrm{CV})$ " and "discriminant validity" (DV). To conduct CV, first, the researchers used explanatory factor analysis (EFA) by using the principal component analysis method, with varimax rotation and eigenvalue greater than one. The 26 items of the study were subject to the EFA. The KMO "Kaiser-Myer-Olkin" test and "Bartlett's test" were employed to identify the stability of the factor analysis. The value of the KMO test was 0.810 , overpassing the threshold of accepted value (60\%). indicating the adequacy of the sample [89]. Bartlett's test produced an approximation of $\chi^{2}=6579.299(\mathrm{df}=276, p<0.001)$, indicating that the sufficiency of the size of the correlations between variables, which indicates the suitability of the data for performing factor analysis. The EFA test resulted in four factors explaining an overall variance of $61.5 \%$ this value was higher than the recommended value of $50 \%$ [90]. The values of the items' loading are presented in Table 5.

Next, a "confirmatory factor analysis" (CFA) was applied to test the variables, and "convergent validity test $(\mathrm{CV})$ " was performed for this intent. $\mathrm{CV}$ determines "the extent to which a measure correlates positively with alternative measures of the same constructs" [91] (p. 112). To assess the CV of the constructs, checking the average variance extracted (AVE) and items' loading values are required. According to Hair et al. [91], the items with low loadings can be removed if higher loading items were able alone to explain around 50 percent of the variance in the construct. Therefore, the researchers retained one item (Eng 1) from the first construct since it was less than 0.40, then, the AVE value of each construct was estimated, and it was found to be adequate for all of them (See Table 5). The second convergent validity measurement was "Composite reliability" (CR). As it was mentioned by Hair et al. [91], CR was determining the internal consistency. The CR test showed that the threshold of its values was exceeding " 0.7 " for each construct, and they are within the accepted range $[92,93]$. Table 5 presents the convergent validity values.

Secondly, the authors conducted discriminant validity. Discriminant validity is used to assess the validity of the constructs and assure its distinctions compared to other constructs, as it was suggested by Fornell and Larcker [94]. Following the recommendations of [94], we calculated "the square root of the AVE" of the constructs. Next, we compared these values with the values of the correlations among the study constructs, as it is presented in Table 6. The value of "the square roots of AVE" should be higher than the values of the correlation among the constructs, which indicates that the study tool is considered as validated [94].

The flowchart of the methods is displayed in Figure 2. 
Table 5. Reliability, convergent validity, and item loadings of the constructs.

\begin{tabular}{|c|c|c|c|c|c|}
\hline Variables & Items & Items Loadings & $\mathrm{CR}$ & AVE & Alpha's Cronbach \\
\hline \multirow{9}{*}{$\begin{array}{c}\text { Work } \\
\text { Engagement }\end{array}$} & Eng1 & Item deleted. & \multirow{9}{*}{0.81} & \multirow{9}{*}{0.51} & \multirow{9}{*}{0.88} \\
\hline & Eng2 & 0.703 & & & \\
\hline & Eng3 & 0.795 & & & \\
\hline & Eng4 & 0.774 & & & \\
\hline & Eng5 & 0.575 & & & \\
\hline & Eng6 & 0.733 & & & \\
\hline & Eng7 & 0.743 & & & \\
\hline & Eng8 & 0.837 & & & \\
\hline & Eng9 & 0.511 & & & \\
\hline \multirow{7}{*}{ Trust } & $\operatorname{Tr} 1$ & 0.720 & \multirow{7}{*}{0.78} & \multirow{7}{*}{0.51} & \multirow{7}{*}{0.84} \\
\hline & $\operatorname{Tr} 2$ & 0.579 & & & \\
\hline & $\operatorname{Tr} 3$ & 0.747 & & & \\
\hline & $\operatorname{Tr} 4$ & 0.770 & & & \\
\hline & $\operatorname{Tr} 5$ & 0.631 & & & \\
\hline & $\operatorname{Tr} 6$ & 0.804 & & & \\
\hline & $\operatorname{Tr} 7$ & 0.690 & & & \\
\hline \multirow{4}{*}{ Job insecurity } & JIS1 & 0.826 & \multirow{4}{*}{0.83} & \multirow{4}{*}{0.66} & \multirow{4}{*}{0.89} \\
\hline & JIS2 & 0.721 & & & \\
\hline & JIS3 & 0.785 & & & \\
\hline & JIS4 & 0.900 & & & \\
\hline \multirow{6}{*}{$\begin{array}{c}\text { Diversity } \\
\text { management }\end{array}$} & DM1 & 0.678 & \multirow{6}{*}{0.76} & \multirow{6}{*}{0.51} & \multirow{6}{*}{0.77} \\
\hline & DM2 & 0.655 & & & \\
\hline & DM3 & 0.766 & & & \\
\hline & DM4 & 0.777 & & & \\
\hline & DM5 & 0.712 & & & \\
\hline & DM6 & 0.690 & & & \\
\hline
\end{tabular}

Note: the full questionnaire statements are displayed in Appendix A (Table A1).

Table 6. Discriminant validity-Fornell-Larcker.

\begin{tabular}{ccccccc}
\hline Variables & Mean & SD & $\mathbf{1}$ & $\mathbf{2}$ & $\mathbf{3}$ & $\mathbf{4}$ \\
\hline 1-Diversity management & 3.66 & 0.611 & $\mathbf{( 0 . 7 1 )}$ & & & \\
2-Job insecurity & 2.53 & 0.88 & $-0.295^{* *}$ & $\mathbf{( 0 . 8 1 )}$ & & \\
3-Trust in organization & 3.43 & 0.623 & $0.507^{* *}$ & $-0.241^{* *}$ & $\mathbf{( 0 . 7 1 )}$ & \\
4-Work engagement & 4.60 & 0.870 & $0.299^{* *}$ & $-0.295^{* *}$ & $0.0397^{* *}$ & $\mathbf{( 0 . 7 2 )}$ \\
\hline$* * 0.001$. & & & & & &
\end{tabular}




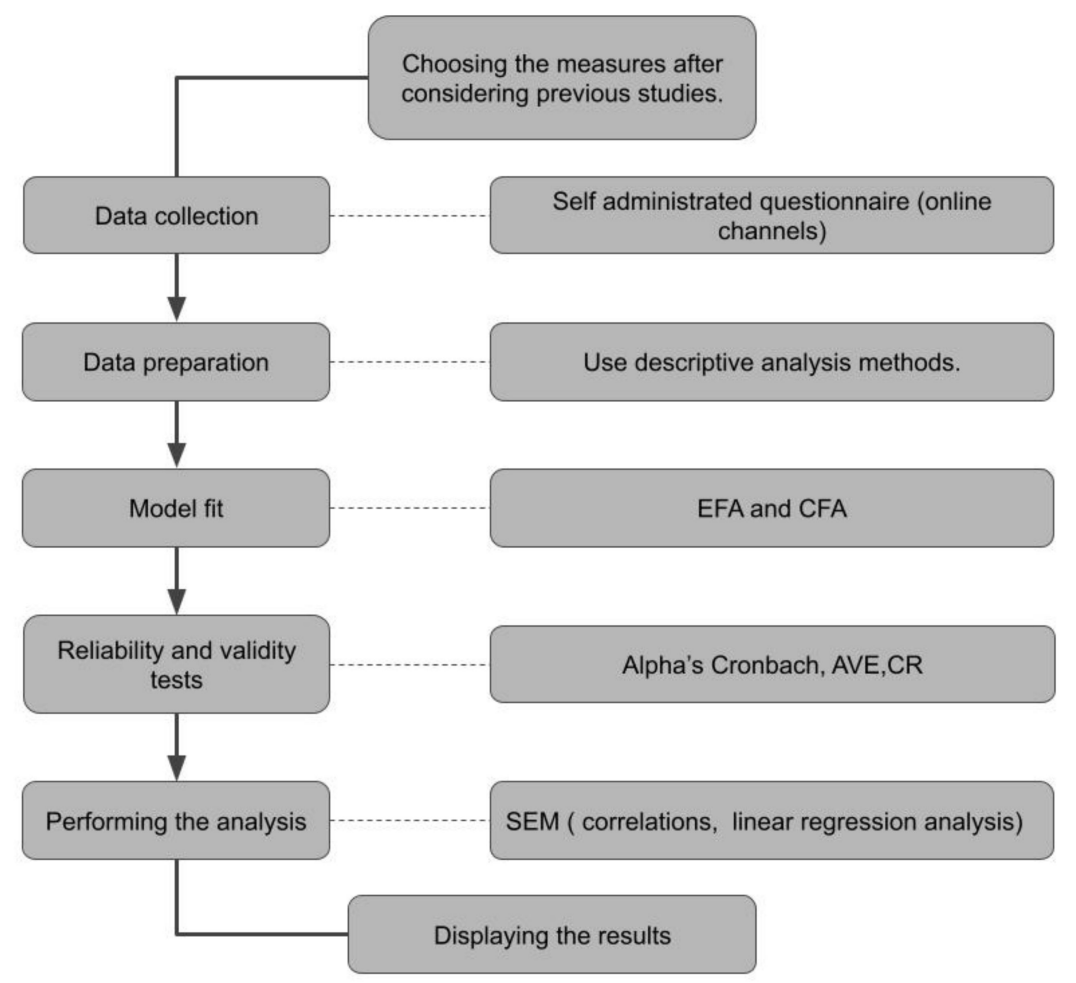

Figure 2. Methods flowchart.

\section{Results}

\subsection{Data Analysis}

To assess the hypothesis of the study, "structural equation modeling" (SEM) was used with the AMOS v.22 packages. To assess the weight of the direct effect of the independent variable over the dependent ones, this study used SEM. The main advantage of SEM is that it provides the possibility to conduct "confirmatory factor analysis" (CFA) and "regression analysis" at the same time, SEM helps in assessing indirect effects as well $[95,96]$.

Hair et al. [96] recommended a method to test the mediation, which consists of two steps. To apply this method the researchers used SEM to assess the hypothesized mediating relationship. Testing the significance of the direct effects between the $X$ variable to the other two variables ( $M$ and $Y$ ) is the first step, the second step is to examine the indirect effect of $\mathrm{X}$ on $\mathrm{Y}$ as follows $(\mathrm{X} \rightarrow \mathrm{M} 1 \rightarrow \mathrm{Y})$ and $(\mathrm{X} \rightarrow \mathrm{M} 2 \rightarrow \mathrm{Y})$. For these purposes, the techniques of SME's path analysis were applied. It is used to evaluate whether the mediation effect between the constructs exists or not and to examine the type of mediation, i.e., full or partial mediation. To determine the level of mediation [97] (p. 89) has described the following points (see Figure 3):

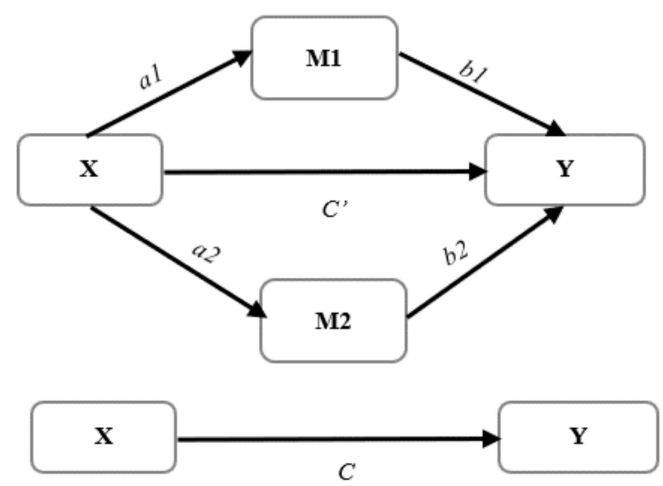

Figure 3. The mediation's theoretical model. 
If $a, b$, and $c$ are significant but the direct coefficient value is $c<b$, then it is partial mediation.

If $\mathrm{a}$ and $\mathrm{b}$ are significant, but $\mathrm{c}$ is not significant, then it is full mediation.

If $\mathrm{a}$ is significant, $\mathrm{b}$ is significant, and $\mathrm{c}$ is also significant, but the coefficient value is $c=b$, it is not mediation.

If $\mathrm{a}$ or $\mathrm{b}$ or both are insignificant, it is not mediation.

\subsection{Hypotheses Test}

The results of the analysis and the hypotheses numbers are presented in Table 7. It describes the direct and indirect effects.

Table 7. SEM results.

\begin{tabular}{|c|c|c|c|c|c|c|}
\hline \multicolumn{2}{|r|}{ Hypotheses (Paths) } & \multirow{2}{*}{$\begin{array}{c}\mathbf{b} \\
-0.390\end{array}$} & \multirow{2}{*}{$\frac{\beta}{-0.277}$} & \multirow{2}{*}{$\begin{array}{c}\text { se } \\
0.071\end{array}$} & \multirow{2}{*}{$\begin{array}{c}\text { T Value } \\
-5.438\end{array}$} & \multirow{2}{*}{$\underbrace{p \text { Value }}_{* * *}$} \\
\hline H5 (a2) & Diversity management $\rightarrow$ Job insecurity & & & & & \\
\hline H2 (a1) & Diversity management $\rightarrow$ Org. trust & 0.440 & 0.437 & 0.047 & 9.403 & $* * *$ \\
\hline H6 (b1) & Job insecurity $\rightarrow$ Employees' engagement & -0.225 & -0.213 & 0.053 & -4.250 & $* * *$ \\
\hline H3 (b2) & Org. trust $\rightarrow$ Employees' engagement & 0.430 & 0.289 & 0.081 & 5.313 & $* * *$ \\
\hline \multirow[t]{10}{*}{$\mathrm{H} 1\left(c^{\prime}\right)$} & Diversity management $\rightarrow$ Employees' engagement & 0.156 & 0.104 & 0.081 & 1.930 & 0.550 \\
\hline & Gender $\rightarrow$ Employees' engagement & 0.032 & 0.017 & 0.092 & .343 & 0.730 \\
\hline & Education $\rightarrow$ Employees' engagement & 0.210 & 0.250 & 0.044 & 4.734 & $* * *$ \\
\hline & Age $\rightarrow$ Employees' engagement & -0.199 & -0.135 & 0.087 & -2.274 & 0.023 \\
\hline & & & Job & rity & & \\
\hline & $\mathrm{R}^{2}$ & & & & & \\
\hline & & & Employe & agement & & \\
\hline & $\mathrm{F}$ & & & & & \\
\hline & DF & & & & & \\
\hline & \multicolumn{6}{|c|}{ Indirect effect } \\
\hline H7 & Diversity $\rightarrow$ job insecurity $\rightarrow$ Engagement & & & 0.088 & \multirow{2}{*}{\multicolumn{2}{|c|}{$\begin{array}{c}\text { (LLCI: } 0.043-\mathrm{ULCI}: \\
0.154) \\
\text { (LLCI: } 0.124-\mathrm{ULCI}: \\
0.308)\end{array}$}} \\
\hline $\mathrm{H} 4$ & Diversity $\rightarrow$ Org. trust $\rightarrow$ Engagement & & & 0.189 & & \\
\hline
\end{tabular}

$* * * * 0.001$.

The analysis of the results are shown in Table 7 . The results explained that diversity management is associated directly with employees' engagement $(\beta=0.288, p<0.001)$, indicating that proper diversity management practices can positively influence the employees to be more engaged at the workplace. Additionally, the path analysis revealed that diversity management is positively associated with organizational trust $(\beta=0.440, p<0.001)$ and negatively associated with job insecurity $(\beta=-0.282, p<0.001)$. These results have confirmed hypotheses (Hypothesis 1,2 and 5), which show that there is a direct effect of diversity management on organizational trust, job insecurity, and employees' engagement.

Furthermore, organizational trust is positively associated with employees' engagement $(\beta=0.290, p<0.01)$, whereas job insecurity is negatively impacting employee engagement $(\beta$ $=-0.187, p<0.01)$, these results lead us to accept Hypotheses 3 and 6 , which indicates that organizational trust and job insecurity are significantly linked with employees' engagement.

Following the suggestions of Hair et al. [97], who mentioned that "full median exists if (a) and (b) direct effects are significant but (c) is not significant", it is evident from the results (Table 7) that organizational trust positively and significantly mediates the effect of diversity management on employee engagement. As suggested by [96], this mediation is a full mediation. Whereas job insecurity significantly and negatively mediates the relationship between diversity management on employees' engagement, and this mediation is full mediation as well. Both mediators were significantly mediating the relationship between diversity management and employees' engagement since the direct effect (path $c^{\prime}$ ) became insignificant and decreased pointedly $(\beta=0.107, p=0.550)$ in the existence of organizational trust and job insecurity. 
As it may be noted, both organizational trust and job insecurity mediates the relationship between diversity management and employee engagement. Organizational trust was a stronger mediator compared to job insecurity. That implies that the impact of diversity management within Hungarian organizations on their employees' engagement can be explained by the presence of organizational trust and job insecurity together. If employees are getting more trust towards their organization or have lower levels of job insecurity, then it is more likely that the diversity management practices that are applied by their organization will be more reflected on the employees' engagement. These results support Hypotheses 4 and 7, which assert that organizational trust and job insecurity mediate the relationship between diversity management and employees' engagement. The results of the hypothesis tests are shown in Figure 4, where standard coefficients are presented.

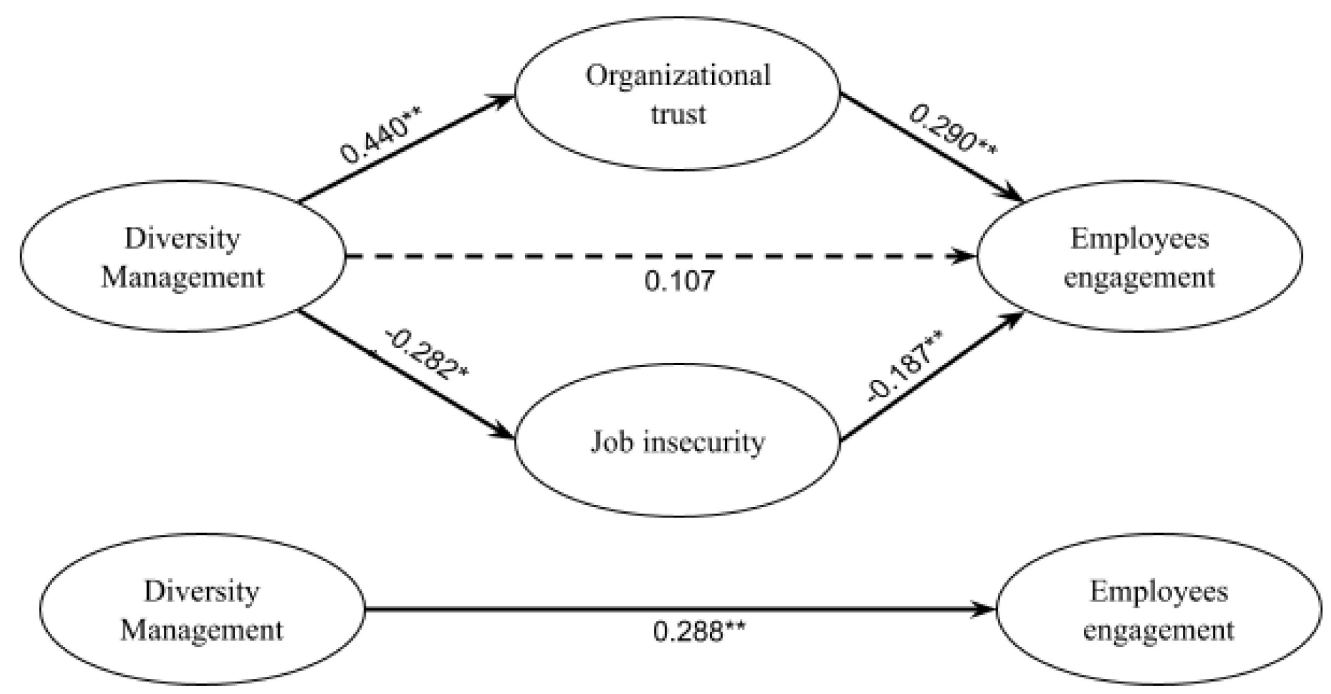

Figure 4. Hypotheses tests (standard estimates); ${ }^{* *} p<0.001 ;{ }^{*} p<0.05$.

\section{Discussion}

This study aimed at investigating the influence of diversity management on employees' engagement and determine the role of organizational trust and job insecurity in that relationship. To do so, the study used quantitative methods to test the results, and the data was analyzed by using SEM procedures. The results confirmed the initial hypothesis that was suggested by the current research.

First, the results indicated that diversity management boosts employees' engagement. The direct relationship between the two variables is considered as a very important job outcome for any organization [98] and is in line with social exchange theory (SET). This explains that when employees perceive diversity management practices from their organizations, they manifest different positive attitudes and behaviors such as organizational commitment [99] and organizational citizenship behaviors [100]. In the context of employees' engagement, SET also suggests that when employees perceive the practices of the management positively, they tend to be more motivated and engaged at their workplace as an exchange toward the positively perceived practices [29]. Therefore, our results can be explained under the context of SET, where diversity management practices are perceived as a positive intention from the organization towards its employees who, in turn, exchange it with more engagement and more enthusiasm.

The direct effect of diversity management on employees' engagement in our study was at moderate level, which comes in line with different previous studies that were taken place in different market segments (e.g., [9,38,39]), which assure the importance of diversity management as a prime factor in creating engaged employees that are full of motivation and enthusiasm toward their work. Especially in the current time where the pandemic's results are still affecting the organizations and the employees where job 
insecurities are increasing because of the instability in work conditions especially among the foreign employees who are considered the most vulnerable segment of the employees [14]. This result comes to support the results in a previous study that indicated the role of perceived organizational support on enhancing employees' engagement in the context of SET. Indicating the importance of the organization's management in providing support to the employees to make them more engaged at work [38] and since diversity management is important to show how the organization support the employees and care about them [33] from these aspects it can be concluded that the role of diversity management is fundamental in achieving engaged employees at work. The indirect relationship between diversity management and employees' engagement was tested by using two different variables: organizational trust and job insecurity.

The results showed that diversity management has a direct negative impact on job insecurity indicating the role of diversity management in decreasing job insecurity between the employees and these results are in line with [68]. In addition, the results are similar to those presented by [69], who found that the absence of clear diversity management practices and policies has a significant impact on increasing job security. Although the impact of diversity management in decreasing job insecurity was relatively at a low level, it was significantly affecting the feelings of job insecurity among the foreign employees in Hungary, indicating the theory of motivation [58], which indicates that when employees perceive diversity management practices positively, they will be more motivated at work and hence their levels of job insecurity will decrease.

On the other hand, the results also show that there is a direct relationship between diversity management and organizational trust, indicating that diversity management enhances trust in organization. Our results are consistent with previous studies that shed light on the relationship between diversity management and organizational trust such as [10], who explained that diversity management practices can increase the perceived fairness among the employees which is translated into organizational trust.

According to Shen et al. [101], organizational trust is influenced directly by the organizational policies and practices that are performed by HR management, and since diversity management is considered as an important part of the policies and practices of HR management [102]. Our findings are consistent with these results, indicating on the role of diversity management in predicting organizational trust.

The results also revealed that organizational trust is an important predictor of employees' engagement. This implies that the more trust in an organization is perceived by the employees, the more they are engaged at work. It is clearly in accordance with SET, which emphasizes that when employees perceive trust in their organization and management, they exchange it with better work outcomes in order to fulfill their responsibilities at work [103]. The current results are in line with different studies that indicated on the importance of organizational trust in achieving better-engaged employees [18,104]. These results are consistent with different recent studies that tried to connect organizational trust with different work outcomes [105-108].

The results related to the impact of job insecurity on employees' engagement showed that job insecurity negatively affected the employees' engagement however this impact was relatively low. Indicating the importance that having employees with job insecurity can negatively affect their engagement at work these results are in line with [70,74]. Yu et al. [109] explained that when employees perceive job insecurity, they tend to develop negative emotions which in the trust will decrease the levels of work engagement. The current result is inconsistent with different studies that linked having job insecurity with negative work outcomes [17,110].

The results also showed that organizational trust positively mediated the relationship between diversity management and employees' engagement, indicating the positive role of trust as a mediator. This result is in line with [9], who indicated the effectiveness as a mediator between diversity management and employees' engagement. This result 
also indicated the importance of organizational trust as a mediator between diversity management and different work outcomes [38,56,101].

On the other hand, job insecurity was negatively mediating the relationship between diversity management and employees' engagement, indicating that job insecurity could negatively reduce the effect of diversity management on employees' engagement. However, this effect is not strong, which indicates that diversity management is an effective tool in decreasing job insecurity among the foreign employees in Hungary in times of uncertainty as the pandemic is still hitting. This result is in line with De Beer et al. [77], who mentioned that the HR policies and practices related to diversity and discrimination could decrease the levels of job insecurity among the American employees and it reflected directly towards their engagement at work.

\section{Conclusions}

In our research, we were able to propound several theoretical and managerial implications. With applying the study in the Hungarian context, we managed to go through the up to date conceptualization of diversity management and cover the theoretical and empirical gaps of the forgoing literature that was linking employees' engagement to job satisfaction, organizational commitment, and leadership styles [36] and where earlier scholars, despite of the world change and the increase in migration movements, missed out to highlight the importance of diversity management, which is currently absent in most Hungarian companies and in some of the Hungarian managers' culture. Therefore, with the press on social exchange theory [26], we were first successfully capable of approving and confirming the significant impact of diversity management, not only on employees' motivation and satisfaction but also on their engagement. Second, we demonstrated that organizational trust could be considered as a mediating variable between diversity management and employee engagement, as diversity management is the best practice to ensure fairness, respect, and appreciation, which can also contribute to increasing the level of organizational trust, which is examined afterward as an important factor to make the employees concentrate on their work, feel concerned about the whole company's issues, and feel motivated and highly engaged. In addition to these two theoretical implications, we were also able to highlight and confirm the negative significant effect of job insecurity and its mediating role between diversity management and employees' engagement. With the help of cognitive appraisal theory [111], we managed to approve that the absence of diversity management could lead to higher levels of job insecurity, job injustice, and less fair payment, which in turn negatively affects the employees' organizational citizenship behaviors and their engagement toward their jobs and roles.

In addition to the previously mentioned theoretical contributions, managerial implications were also reachable and are very important to highlight. First, it seems conspicuous that managing diversity in the workplace is of an increasingly significant concern nowadays, and it has widely been mentioned from business perspectives that most employers should hugely consider it in their corporate culture. However, this is less common for Hungarian employers, which is why our study opens a good development area for this issue. We suggest to these managers who are working for service companies to increase their general awareness around workplace diversity by fostering diversity during the recruitment process by hiring people from different backgrounds, ages, gender, and cultures, etc., and boost their employment relationships thereafter. In addition, internal policies should be implemented aiming at minimizing violation and ensuring equal treatment principles. We think that providing proper training around conflict management, teamwork, and cooperation is critical to involving and flourishing a diverse workplace. Second, we pointed out how organizational trust could be important to deal with the diversity in Hungarian service companies and how it could affect the employees' engagement. It is absolutely, important to know that implementing trust within the organization is not only the managers' responsibility but also the employees' responsibility. That is why they should always try to be aware of their changing needs, take care of their own growth, and 
always try to transfer that to their managers to build a certain trust level and boost their satisfaction, motivation, commitment towards their jobs, and, of course, their engagement. Furthermore, implementing well-structured diversity management strategies is a significant tool to raise trust between the different organizations' parties that helps in increasing knowledge exchange and positively impacts employees' engagement. Finally, our study was also engaged in opening another area related to job insecurities. It has been proven that in Hungary, women and foreigners are those who are really facing the most shocking forms of direct and indirect discrimination in the workplace. This fact has generated high levels of job insecurities leading to these workers' engagement decrease. Consequently, our study is considered as a pillar encouraging companies to favorize diversity management policies implementation to avoid any feeling of job insecurities, inequalities, discrimination, or violation, so that they can be able to provide a great work atmosphere and conditions for better performance and higher engagements.

Despite, the great contributions provided by our research, we were not able to escape some of the limitations that took place. First, as we adopted a causal relationship statistic method, we had to face the risk of bias, which was hard to remove, despite the huge effort made in ensuring a complete approximation of collinearity and an absolute validation of the variables' connections mentioned in the literature review. To skip this problem, we suggest future studies to adopt longitudinal research in order to investigate the links between the variables and provide well-grounded and solid results. Second, choosing only the Hungarian context to confirm our hypothesis especially from Hungarian managers perspective who are working for Hungarian service companies, was a reason for reducing the generalizability of the paper. Consequently, future examinations are advised to go through a probabilistic sampling method and generalize the study model in other countries and in other situational or environmental contexts such as crisis times, where we can have a concrete example the COVID-19 pandemic time and see the changes that may occur in the model. Third, it is highly recommended to use our research model and add some other moderating and mediating variables to see to what extent these variables could affect the relationship between diversity management and employees' engagement. As an example, future studies could abord these variables as an example: knowledge sharing, communication, and leadership styles, etc. Finally, we also suggest to other researchers to conduct a qualitative study to confirm our results.

Author Contributions: Conceptualization, A.A.; methodology, A.A.; software, A.A.; validation, A.A. and I.R.; formal analysis, A.A.; investigation, K.A.H.; resources, A.A. and K.A.H.; data curation, A.A. and K.A.H.; writing-original draft preparation, K.A.H. and A.A.; writing-review and editing, K.A.H. and A.A.; visualization, A.A.; supervision, I.R.; project administration, A.A.; funding acquisition, I.R. All authors have read and agreed to the published version of the manuscript.

Funding: There is no funding provided for this research.

Institutional Review Board Statement: Ethical review and approval were waived for this study due to the fact that we used anonymous data that were not traceable to individuals at any time.

Informed Consent Statement: Informed consent was obtained from all the employees who participated in the questionnaire.

Data Availability Statement: Not applicable.

Conflicts of Interest: The authors declare no conflict of interest. 


\section{Appendix A}

Table A1. The study's questionnaire.

\begin{tabular}{|c|c|}
\hline Code & The Statement \\
\hline \multicolumn{2}{|r|}{ Diversity management } \\
\hline DM1 & $\begin{array}{c}\text { Managers in this company have a track record of hiring and promoting employees } \\
\text { regardless of religion, sect, or ethnicity. }\end{array}$ \\
\hline DM2 & $\begin{array}{c}\text { Employees here are treated fairly regarding promotion without consideration of } \\
\text { their religion, sect, or ethnicity. }\end{array}$ \\
\hline DM3 & $\begin{array}{c}\text { Compensation and benefits policies are applied objectively to all employees } \\
\text { regardless of religion, sect, or ethnicity. }\end{array}$ \\
\hline DM4 & $\begin{array}{c}\text { Training \& development opportunities are offered to employees objectively } \\
\text { regardless of religion, sect, or ethnicity. }\end{array}$ \\
\hline DM5 & $\begin{array}{c}\text { Employees' performance is evaluated objectively regardless of religion, sect, } \\
\text { or ethnicity. }\end{array}$ \\
\hline DM6 & $\begin{array}{l}\text { In this company, there is a general atmosphere of inclusion, tolerance, and } \\
\text { acceptance of the other. }\end{array}$ \\
\hline \multicolumn{2}{|r|}{ Job insecurity } \\
\hline JIS1 & Chances are, I will soon lose my job. \\
\hline JIS2 & I am afraid that I may not be able to keep my job. \\
\hline JIS3 & I feel insecure about the future of my job. \\
\hline JIS4 & I think I might lose my job in the near future. \\
\hline \multicolumn{2}{|r|}{ Organizational trust } \\
\hline $\operatorname{Tr} 1$ & I believe that the management of my company has high integrity \\
\hline $\operatorname{Tr} 2$ & $\begin{array}{l}\text { I can expect my organizations' management to treat me in a consistent and } \\
\text { predictable fashion }\end{array}$ \\
\hline $\operatorname{Tr} 3$ & My organization's management is not always honest and truthful \\
\hline $\operatorname{Tr} 4$ & In general, I believe my organizations' management motives and intentions are good \\
\hline $\operatorname{Tr} 5$ & I don't think my organizations' management treats me fairly \\
\hline Tr6 & My organization's management is open and upfront with me \\
\hline $\operatorname{Tr} 7$ & I am not sure I fully trust my organizations' management \\
\hline \multicolumn{2}{|r|}{ Employees' engagement } \\
\hline Eng1 & At my work, I feel bursting with energy \\
\hline Eng2 & At my job, I feel strong and vigorous \\
\hline Eng3 & I am enthusiastic about my job \\
\hline Eng4 & My job inspires me \\
\hline Eng5 & When I get up in the morning, I feel like going to work \\
\hline Eng6 & I feel happy when I am working intensely \\
\hline Eng7 & I am proud of the work that I do \\
\hline Eng8 & I am immersed in my work \\
\hline Eng9 & Time flies when I am working \\
\hline
\end{tabular}

\section{References}

1. Seliverstova, Y. Workforce diversity management: A systematic literature review. Strat. Manag. 2021, 26, 3-11. [CrossRef]

2. Ateş, A.; Ünal, A. The Relationship between Diversity Management, Job Satisfaction and Organizational Commitment in Teachers: A Mediating Role of Perceived Organizational Support. Educ. Sci. Theory Pract. 2021, 21, 18-32. [CrossRef]

3. Itam, U.; Bagali, M.M. Diversity and Inclusion Management: A Focus on Employee Engagement. In Gender and Diversity: Concepts, Methodologies, Tools, and Applications; IGI Global: Hershey, PA, USA, 2019; pp. 1771-1788.

4. Johnston, W.B.; Packer, A.E. Workforce 2000: Work and Workers for the 21st Century; Hudson Institute: Washington, DC, USA, 1987.

5. Caudron, S.; Hayes, C. Are diversity programs benefiting African Americans? Black Enterp. 1997, 27, 121-136.

6. Sukalova, V.; Ceniga, P. Diversity Management in Sustainable Human Resources Management. In SHS Web of Conferences; EDP Sciences: Les Ulis, France, 2020; Volume 74, p. 01033. [CrossRef]

7. Józefowicz, B. Diversity Management and Trust: Systematic Literature Review. J. Corp. Responsib. Leadersh. 2017, 4, 51-68. [CrossRef]

8. Horvath, A.; Vidra, Z.; Fox, J. Tolerance and cultural diversity discourses in Hungary. In Ploicy Research Reports; Central European University: Budapest, Hungary, 2011; pp. 1-36. 
9. Downey, S.N.; van der Werff, L.; Thomas, K.; Plaut, V.C. The role of diversity practices and inclusion in promoting trust and employee engagement. J. Appl. Soc. Psychol. 2015, 45, 35-44. [CrossRef]

10. Bizri, R. Diversity management and OCB: The connection evidence from the Lebanese banking sector. Equal. Divers. Incl. Int. J. 2018, 37, 233-253. [CrossRef]

11. Ahanchian, M.; Ganji, S.F.G. The effect of perceptions of ethical context on job satisfaction with emphasis on work values: The case of female staff at an Iranian university. Int. J. Work Organ. Emot. 2017, 8, 118. [CrossRef]

12. Valentine, S.; Godkin, L. Banking Employees' Perceptions of Corporate Social Responsibility, Value-Fit Commitment, and Turnover Intentions: Ethics as Social Glue and Attachment. Empl. Responsib. Rights J. 2017, 29, 51-71. [CrossRef]

13. Van De Voorde, K.; Paauwe, J.; van Veldhoven, M. Employee Well-being and the HRM-Organizational Performance Relationship: A Review of Quantitative Studies. Int. J. Manag. Rev. 2012, 14, 391-407. [CrossRef]

14. Guadagno, L. Migrants and the COVID-19 pandemic: An initial analysis. In Migration Research Series; International Organisation for Migration (IOM): Geneva, Switzerland, 2020.

15. Ibrahim, S.N.H.; Suan, C.L.; Karatepe, O.M. The effects of supervisor support and self-efficacy on call center employees' work engagement and quitting intentions. Int. J. Manpow. 2019, 40, 688-703. [CrossRef]

16. Cheung, S.Y.; Gong, Y.; Huang, J.-C. Emotional intelligence, job insecurity, and psychological strain among real estate agents: A test of mediation and moderation models. Int. J. Hum. Resour. Manag. 2016, 27, 2673-2694. [CrossRef]

17. Etehadi, B.; Karatepe, O.M. The impact of job insecurity on critical hotel employee outcomes: The mediating role of self-efficacy. J. Hosp. Mark. Manag. 2018, 28, 665-689. [CrossRef]

18. Ugwu, F.; Onyishi, I.; Rodríguez-Sánchez, A.M. Linking organizational trust with employee engagement: The role of psychological empowerment. Pers. Rev. 2014, 43, 377-400. [CrossRef]

19. Oppenheimer, D.B. Supplementary data: The disappearance of voluntary affirmative action from the US workplace. J. Poverty Soc. Justice 2016, 24, 37-50. [CrossRef]

20. Köllen, T. Diversity Management: A Critical Review and Agenda for the Future. J. Manag. Inq. 2021, 30, 259-272. [CrossRef]

21. Yadav, S.; Lenka, U. Diversity management: A systematic review. Equal. Divers. Inclusion: Int. J. 2020, 39, 901-929. [CrossRef]

22. Jackson, S.E.; Joshi, A.; Erhardt, N.L. Recent Research on Team and Organizational Diversity: SWOT Analysis and Implications. J. Manag. 2003, 29, 801-830. [CrossRef]

23. Thomas, R.R. From affirmative action to affirming diversity. Harv. Bus. Rev. 1990, 68, 107-117. [PubMed]

24. Tajfel, H.; Turner, J.C.; Austin, W.G.; Worchel, S. An integrative theory of intergroup conflict. In Organizational Identity: A Reader; Oxford University Press: Oxford, UK, 2004; p. 586.

25. Byrne, D. An Overview (and Underview) of Research and Theory within the Attraction Paradigm. J. Soc. Pers. Relatsh. 1997, 14, 417-431. [CrossRef]

26. Gouldner, A.W. The Norm of Reciprocity: A Preliminary Statement. Am. Sociol. Rev. 1960, 25, 161. [CrossRef]

27. Horváthová, P.; Mikušová, M.; Kashi, K. Evaluation of the employees' engagement factors importance methodology including generation Y. Econ. Res.-Ekon. Istraživanja 2019, 32, 3895-3917. [CrossRef]

28. Armstrong, M.; Taylor, S. Armstrong's Handbook of Human Resource Management Practice, 14th ed.; Kogan Page: London, UK, 2017.

29. Kahn, W.A. Psychological Conditions of Personal Engagement and Disengagement at Work. Acad. Manag. J. 1990, 33, 692-724. [CrossRef]

30. Schaufeli, W.B.; Salanova, M.; González-Romá, V.; Bakker, A.B. The Measurement of Engagement and Burnout: A Two Sample Confirmatory Factor Analytic Approach. J. Happiness Stud. 2002, 3, 71-92. [CrossRef]

31. Schaufeli, W.B.; Bakker, A.B.; Salanova, M. The measurement of work engagement with a short ques-tionnaire: A cross-national study. Educ. Psychol. Meas. 2006, 66, 701-716. [CrossRef]

32. Ghasempour Gangi, S.F.; Kafahpour, A. A Survey of the Mediating Role of Perceived Organizational Support in the Relationship between Ethical Context and Female Employees' Job Response. Q. J. Women Soc. 2017, 7, 1-18.

33. Ganji, S.F.G.; Nia, F.R.; Ahanchian, M.R.; Syed, J. Analyzing the Impact of Diversity Management on Innovative Behaviors through Employee Engagement and Affective Commitment. Iran. J. Manag. Stud. 2020, 14, 649-667.

34. Ganji, S.F.G.; Johnson, L.W. The Relationship between Family Emotional Support, Psychological Capital, Female Job Satisfaction and Turnover Intention. Int. J. Econ. Bus. Manag. Stud. 2020, 7, 59-70. [CrossRef]

35. O'Connor, E.P.; Crowley-Henry, M. Exploring the Relationship Between Exclusive Talent Management, Perceived Organizational Justice and Employee Engagement: Bridging the Literature. J. Bus. Ethics 2017, 156, 903-917. [CrossRef]

36. Hapsari, C.; Stoffers, J.; Gunawan, A. The Influence of Generational Diversity Management and Leader-Member Exchange on Innovative Work Behaviors Mediated by Employee Engagement. J. Asia-Pac. Bus. 2019, 20, 125-139. [CrossRef]

37. Alshaabani, A.; Benedek, A. Trust Climate and Distributive Justice As Mediators Between Diversity Management Practices and Employees' Behaviors. Acta Carolus Robertus 2018, 8, 5-16.

38. Alshaabani, A.; Naz, F.; Magda, R.; Rudnák, I. Impact of Perceived Organizational Support on OCB in the Time of COVID-19 Pandemic in Hungary: Employee Engagement and Affective Commitment as Mediators. Sustainability 2021, 13, 7800. [CrossRef]

39. Skalsky, P.; McCarthy, G. Diversity Management in Australia and Its Impacton Employee Engagement; World at Work: Scottsdale, AZ, USA, 2009; p. 5.

40. Berraies, S.; Hamza, K.A.; Chtioui, R. Distributed leadership and exploratory and exploitative innovations: Mediating roles of tacit and explicit knowledge sharing and organizational trust. J. Knowl. Manag. 2021, 25, 1287-1318. [CrossRef] 
41. Hon, L.C.; Grunig, J.E. Guidelines for Measuring Relationships in Public Relations; Institute for Public Relations: Gainesville, FL, USA, 1999

42. Nyhan, R.C.; Marlowe, H.A. Development and Psychometric Properties of the Organizational Trust Inventory. Eval. Rev. 1997, 21, 614-635. [CrossRef]

43. Lee, Y.; Li, J.Q. The role of communication transparency and organizational trust in publics' perceptions, attitudes and social distancing behaviour: A case study of the COVID-19 outbreak. J. Conting. Crisis Manag. 2021, 29, 368-384. [CrossRef]

44. Alshaabani, A.; Oláh, J.; Popp, J.; Zaien, S. Impact of Distributive Justice on the Trust Climate among Middle Eastern Employees Pol. J. Manag. Stud. 2020, 21, 34-47. [CrossRef]

45. Alshaabani, A.; Rudnák, I. Impact of Diversity Management Practices on Organizational Climate-An Egyptian Study. J. Manag. 2020, 36, 7-17. [CrossRef]

46. Gao, Y.; He, W. Corporate social responsibility and employee organizational citizenship behavior. Manag. Decis. 2017, 55, 294-309. [CrossRef]

47. Alas, R.; Mousa, M. Cultural diversity and business schools' curricula: A case from Egypt. Probl. Perspect. Manag. 2016, 14, 130-137. [CrossRef]

48. Roux, S. The Relationship between Authentic Leadership, Optimism, Self-Efficacy and Work Engagement: An Exploratory Study; Stellenbosch University: Stellenbosch, South Africa, 2010; p. 145.

49. Burke, R.J.; El-Kot, G. Work engagement among managers and professionals in Egypt. Afr. J. Econ. Manag. Stud. 2010, 1, 42-60. [CrossRef]

50. Inoue, A.; Kawakami, N.; Ishizaki, M.; Shimazu, A.; Tsuchiya, M.; Tabata, M.; Akiyama, M.; Kitazume, A.; Kuroda, M Organizational justice, psychological distress, and work engagement in Japanese workers. Int. Arch. Occup. Environ. Health 2010, 83, 29-38. [CrossRef]

51. Burke, R.J.; Koyuncu, M.; Jing, W.; Fiksenbaum, L. Work engagement among hotel managers in Beijing, China: Potential antecedents and consequences. Tour. Rev. 2009, 64, 4-18. [CrossRef]

52. Alfes, K.; Shantz, A.; Alahakone, R. Testing additive versus interactive effects of person-organization fit and organizational trust on engagement and performance. Pers. Rev. 2016, 45, 1323-1339. [CrossRef]

53. Wong, C.A.; Laschinger, H.K.S.; Cummings, G.G. Authentic leadership and nurses' voice behaviour and perceptions of care quality. J. Nurs. Manag. 2010, 18, 889-900. [CrossRef]

54. Soni, D.; Mehta, P. Manifestation of Internal CSR on Employee Engagement: Mediating Role of Organizational Trust. Indian J. Ind. Relat. 2020, 55, 441-459.

55. Nguyen, T.T.H.; Pham, T.T.H.; Le, Q.B.; Bui, T.V.A. Impact of corporate social responsibility on organizational commitment through organizational trust and organizational identification. Manag. Sci. Lett. 2020, 10, 3453-3462. [CrossRef]

56. Shen, J.; Tang, N.; D’Netto, B. Effects of HR Diversity Management on Employee Knowledge Sharing: Mediating Role of Trust. Acad. Manag. Proc. 2012, 2012, 13627. [CrossRef]

57. Ward, A.-K.; Beal, D.J.; Zyphur, M.J.; Zhang, H.; Bobko, P. Diversity climate, trust, and turnover intentions: A multilevel dynamic system. J. Appl. Psychol. 2021. [CrossRef]

58. Mahmoud, A.B.; Reisel, W.D.; Fuxman, L.; Mohr, I. A motivational standpoint of job insecurity effects on organizational citizenship behaviors: A generational study. Scand. J. Psychol. 2021, 62, 267-275. [CrossRef]

59. Jung, H.S.; Jung, Y.S.; Yoon, H.H. COVID-19: The effects of job insecurity on the job engagement and turnover intent of deluxe hotel employees and the moderating role of generational characteristics. Int. J. Hosp. Manag. 2021, 92, 102703. [CrossRef]

60. Shoss, M.K. Job Insecurity: An Integrative Review and Agenda for Future Research. J. Manag. 2017, 43, 1911-1939. [CrossRef]

61. Inoue, A.; Kawakami, N.; Eguchi, H.; Tsutsumi, A. Interaction effect of job insecurity and role ambiguity on psychological distress in Japanese employees: A cross-sectional study. Int. Arch. Occup. Environ. Health 2018, 91, 391-402. [CrossRef]

62. Hellgren, J.; Sverke, M.; Isaksson, K. A Two-dimensional Approach to Job Insecurity: Consequences for Employee Attitudes and Well-being. Eur. J. Work Organ. Psychol. 1999, 8, 179-195. [CrossRef]

63. Darvishmotevali, M.; Ali, F. Job insecurity, subjective well-being and job performance: The moderating role of psychological capital. Int. J. Hosp. Manag. 2020, 87, 102462. [CrossRef]

64. Sverke, M.; Hellgren, J. The Nature of Job Insecurity: Understanding Employment Uncertainty on the Brink of a New Millennium. Appl. Psychol. 2002, 51, 23-42. [CrossRef]

65. Keim, A.C.; Landis, R.S.; Pierce, C.A.; Earnest, D.R. Why do employees worry about their jobs? A meta-analytic review of predictors of job insecurity. J. Occup. Health Psychol. 2014, 19, 269-290. [CrossRef]

66. Elst, T.V.; Baillien, E.; De Cuyper, N.; De Witte, H. The role of organizational communication and participation in reducing job insecurity and its negative association with work-related well-being. Econ. Ind. Democr. 2010, 31, 249-264. [CrossRef]

67. Richter, A.; Näswall, K. Job insecurity and trust: Uncovering a mechanism linking job insecurity to well-being. Work Stress 2019, 33, 22-40. [CrossRef]

68. Lavaysse, L.M.; Probst, T.M.; Arena, D.F., Jr. Is More Always Merrier? Intersectionality as an Antecedent of Job Insecurity. Int. J. Environ. Res. Public Health 2018, 15, 2559. [CrossRef]

69. Shen, J.; D'Netto, B.; Tang, J. Effects of human resource diversity management on organizational citizen behaviour in the Chinese context. Int. J. Hum. Resour. Manag. 2010, 21, 2156-2172. [CrossRef]

70. Greenhalgh, L.; Rosenblatt, Z. Evolution of Research on Job Insecurity. Int. Stud. Manag. Organ. 2010, 40, 6-19. [CrossRef] 
71. Presti, A.L.; Nonnis, M. Moderated effects of job insecurity on work engagement and distress. TPM: Test. Psychom. Methodol. Appl. Psychol. 2012, 19, 97-113.

72. Stankevičiūtè, Ž.; Staniškienè, E.; Ramanauskaite, J. The Impact of Job Insecurity on Organisational Citizenship Behaviour and Task Performance: Evidence from Robotised Furniture Sector Companies. Int. J. Environ. Res. Public Health 2021, $18,515$. [CrossRef]

73. Wang, H.-J.; Lu, C.-Q.; Siu, O.-L. Job insecurity and job performance: The moderating role of organizational justice and the mediating role of work engagement. J. Appl. Psychol. 2015, 100, 1249-1258. [CrossRef] [PubMed]

74. Asfaw, A.G.; Chang, C.-C. The association between job insecurity and engagement of employees at work. J. Workplace Behav. Health 2019, 34, 96-110. [CrossRef] [PubMed]

75. Park, J.H.; Ono, M. Effects of workplace bullying on work engagement and health: The mediating role of job insecurity. Int. J. Hum. Resour. Manag. 2016, 28, 3202-3225. [CrossRef]

76. Hsieh, H.-H.; Huang, J.-T. Core Self-Evaluations and Job and Life Satisfaction: The Mediating and Moderated Mediating Role of Job Insecurity. J. Psychol. 2017, 151, 282-298. [CrossRef]

77. De Beer, L.T.; Rothmann, S., Jr.; Pienaar, J. Job insecurity, career opportunities, discrimination and turnover intention in postapartheid South Africa: Examples of informative hypothesis testing. Int. J. Hum. Resour. Manag. 2015, 27, 427-439. [CrossRef]

78. Baruch, Y.; Holtom, B.C. Survey response rate levels and trends in organizational research. Hum. Relat. 2008, 61, 1139-1160. [CrossRef]

79. Baksa, M.; Marciniak, R.; Nagy, D.; Komaromi, R.; Andicsku, A.; Palasti, G.; Szemde, C.; Borbely, R.; Bucsku, G.; Nagy, A.; et al. Business Services Sector Hungary; Marciniak, R., Ránki, R., Eds.; Hungarian Service and Outsourcing Association (HOA): Budapest, Hungary, 2020.

80. Chen, H.; Eyoun, K. Do mindfulness and perceived organizational support work? Fear of COVID-19 on restaurant frontline employees' job insecurity and emotional exhaustion. Int. J. Hosp. Manag. 2020, 94, 102850. [CrossRef]

81. Gabarro, J.; Athos, J. Interpersonal Relations and Communications; Prentice-Hall: Englewood Cliffs, NJ, USA, 1976.

82. Schumacker, R.E.; Lomax, R.G. A Beginner's Guide to Structural Equation Modeling; Lawrence Erlbaum Associates: Mahwah, NJ, USA, 2004.

83. Bentler, P.M. Comparative fit indexes in structural models. Psychol. Bull. 1990, 107, 238-246. [CrossRef]

84. Awang, Z. Structural Equation Modeling Using Amos Graphic; Penerbit Universiti Teknologi MARA: Shah Alam, Malaysia, 2012.

85. Podsakoff, P.M.; MacKenzie, S.B.; Lee, J.Y.; Podsakoff, N.P. Common method biases in behavioral research: A critical review of the literature and recommended remedies. J. Appl. Psychol. 2003, 88, 879-903. [CrossRef]

86. Burton-Jones, A. Minimizing Method Bias through Programmatic Research. MIS Q. 2009, 33, 445-471. [CrossRef]

87. Favero, N.; Bullock, J.B. How (Not) to Solve the Problem: An Evaluation of Scholarly Responses to Common Source Bias. J. Public Adm. Res. Theory 2015, 25, 285-308. [CrossRef]

88. Sekaran, U.; Bougie, R. Research Methods for Business: A skill Building Approach; John Wiley \& Sons: Hoboken, NJ, USA, 2016.

89. Kaiser, H.F. An index of factorial simplicity. Psychometrika 1974, 39, 31-36. [CrossRef]

90. Kline, P. An Easy Guide to Factor Analysis, 1st ed.; Routledge: London, UK, 1994. [CrossRef]

91. Hair, J.F.; Sarstedt, M.; Ringle, C.M.; Gudergan, S.P. Advanced Issues in Partial Least Squares Structural Equation Modeling; Sage Publications: Thousand Oaks, CA, USA, 2018.

92. Chin, W.W. Commentary: Issues and Opinion on Structural Equation Modeling. MIS Q. 1998, 22, 7-16.

93. Bagozzi, R.P.; Yi, Y.; Phillips, L.W. Assessing Construct Validity in Organizational Research. Adm. Sci. Q. 1991, 36, 421. [CrossRef]

94. Fornell, C.; Larcker, D.F. Evaluating Structural Equation Models with Unobservable Variables and Measurement Error. J. Mark. Res. 1981, 18, 39-50. [CrossRef]

95. Kaplan, D. Structural Equation Modeling. In International Encyclopedia of the Social \& Behavioral Sciences; Smelser, N.J., Baltes, P.B., Eds.; Pergamon: Oxford, UK, 2001; pp. 15215-15222.

96. Hair, J.; Anderson, R.; Black, B.; Babin, B. Multivariate Data Analysis. 2016: Pearson Education. Available online: https: / / books.google.hu/books?id=LKOSAgAAQBAJ (accessed on 15 September 2021).

97. Hair, J.F.; Black, W.C.; Babin, B.J. Multivariate Data Analysis: A Global Perspective; Pearson Education: London, UK, 2010.

98. Li, W.; Wang, X.; Haque, J.; Shafique, M.N.; Nawaz, M.Z. Impact of Workforce Diversity Management on Employees' Outcomes: Testing the Mediating Role of a person's Job Match. SAGE Open 2020, 10, 2158244020903402. [CrossRef]

99. Magoshi, E.; Chang, E. Diversity management and the effects on employees' organizational commitment: Evidence from Japan and Korea. J. World Bus. 2009, 44, 31-40. [CrossRef]

100. Moshabaki, A.; Madani, F.; Ghorbani, H. An investigation of the role of human resource diversity management on organisational citizenship behaviour from organisational justice and commitment point of view in automotive industry in Iran. Int. J. Manag. Enterp. Dev. 2013, 12, 331. [CrossRef]

101. Shen, J.; Tang, N.; D'Netto, B. A multilevel analysis of the effects of HR diversity management on employee knowledge sharing: The case of Chinese employees. Int. J. Hum. Resour. Manag. 2013, 25, 1720-1738. [CrossRef]

102. Ollapally, A.; Bhatnagar, J. The holistic approach to diversity management: HR implications. Indian J. Ind. Relat. 2009, 44, 454-472 Available online: https:/ / www.jstor.org/stable/27768218 (accessed on 15 September 2021).

103. Saks, A.M. Antecedents and consequences of employee engagement. J. Manag. Psychol. 2006, 21, 600-619. [CrossRef] 
104. Hough, C.; Green, K.; Plumlee, G. Impact of ethics environment and organizational trust on employee engagement. J. Leg. Ethical Regul. Issues 2015, 18, 45-62.

105. Loes, C.N.; Tobin, M.B. Organizational Trust, Psychological Empowerment, and Organizational Commitment Among Licensed Practical Nurses. Nurs. Adm. Q. 2020, 44, 179-187. [CrossRef] [PubMed]

106. Ilyas, S.; Abid, G.; Ashfaq, F. Ethical leadership in sustainable organizations: The moderating role of general self-efficacy and the mediating role of organizational trust. Sustain. Prod. Consum. 2020, 22, 195-204. [CrossRef]

107. Guzzo, R.F.; Wang, X.; Madera, J.M.; Abbott, J. Organizational trust in times of COVID-19: Hospitality employees' affective responses to managers' communication. Int. J. Hosp. Manag. 2021, 93, 102778. [CrossRef]

108. Bulińska-Stangrecka, H.; Iddagoda, Y.A. The Relationship between Inter-Organizational Trust and Employee Engagement and Performance; Academy of Management: Briarcliff Manor, NY, USA, 2020; p. 4.

109. Yu, S.; Gong, X.; Wu, N. Job Insecurity and Employee Engagement: A Moderated Dual Path Model. Sustainability 2020, $12,10081$. [CrossRef]

110. Schumacher, D.; Schreurs, B.; Van Emmerik, H.; De Witte, H. Explaining the Relation Between Job Insecurity and Employee Outcomes During Organizational Change: A Multiple Group Comparison. Hum. Resour. Manag. 2016, 55, 809-827. [CrossRef]

111. Reisenzein, R.; Schönpflug, W. Stumpf's cognitive-evaluative theory of emotion. Am. Psychol. 1992, 47, 34-45. [CrossRef] 